\title{
Ground ice and slope sediments archiving late Quaternary paleoenvironment and paleoclimate signals at the margins of El'gygytgyn Impact Crater, NE Siberia
}

\author{
Georg Schwamborn $^{\mathrm{a}, *}$, Hanno Meyer ${ }^{\mathrm{a}}$, Grigory Fedorov ${ }^{\mathrm{b}}$, \\ Lutz Schirrmeister ${ }^{\text {a }}$, Hans-W. Hubberten ${ }^{\text {a }}$ \\ a Alfred Wegener Institute for Polar and Marine Research, Telegrafenberg A43, D-14473 Potsdam, Germany \\ ${ }^{\mathrm{b}}$ Arctic and Antarctic Research Institute, Bering Street, 199397 St. Petersburg, Russia
}

Received 14 March 2006

Available online 9 August 2006

\begin{abstract}
An accumulation terrace close to the El'gygytgyn Impact Crater in northeastern Siberia contains stratigraphic and periglacial evidence of the paleoenvironmental and paleoclimatic history and permafrost dynamics during late Quaternary time. A succession of paleo active-layer deposits that mirror environmental changes records periods favorable for the establishment and growth of ice-wedge polygonal networks and sediment variations. These two elements of the periglacial landscape serve as complementary paleoenvironmental archives that can be traced back to $\sim 14,000 \mathrm{cal}$ yr BP. The slope sediments and the ground ice contained therein have prominent relative maxima and minima in properties (grain size, total organic content, oxygen isotopes). They document a regional early Holocene thermal maximum at about 9000 cal yr BP, followed by a transition to slightly cooler conditions, and a subsequent transition to slightly warmer conditions after about 4000 cal yr BP. Results from sedimentary analysis resemble morphological and geochemical (oxygen and hydrogen isotopes) results from ice wedge studies, in which successive generations of ice-wedge polygonal networks record warmer winters in late Holocene time. Moreover, peaks of light soluble cation contents and quartz-grain surface textures reveal distinct traces of cryogenic weathering. We propose a conclusive sedimentation model illustrating terrace formation in a permafrost terrain.
\end{abstract}

(C) 2006 University of Washington. All rights reserved.

\section{Introduction}

The Quaternary periglacial record and landforms are essential background information needed to better interpret the catchment environmental history of sediments preserved in El'gygytgyn Crater Lake in Northeastern Siberia (Fig. 1a). The lake, $12 \mathrm{~km}$ in diameter and $170 \mathrm{~m}$ in depth, originated from a meteoritic impact at 3.6 Ma (Layer, 2000) and so is considered to hold an environmental archive back to late Pliocene times. The area was not glaciated during the Quaternary, allowing for continuous sedimentation in the lake basin Glushkova, 2001, Heiser and Roush, 2001). Escaping extensive regional glaciations, continental northeast Siberia was instead subject to permafrost conditions during the Quaternary Kaplina, 1981; Hubberten et al., 2004; Brigham-Grette, 2004), presumably

\footnotetext{
* Corresponding author. Fax: +49 $3312882162 / 37$.

E-mail address: gschwamborn@awi-potsdam.dd (G. Schwamborn).
}

after intensification of northern hemispheric glaciations about $2.6 \mathrm{Ma}$ (Jansen and Sjøholm, 1991). Today, permafrost thickness reaches about $500 \mathrm{~m}$ and slope processes and fluvial activity are the main agents causing erosion, transport and sedimentation in the area (Yershov, 1998).

A 12.7-m lake sediment core spanning time back to ca. $300,000 \mathrm{yr}$ is already available, enabling us to observe paleoenvironmental change at a millennial time scale (Nowaczyk et al., 2002; Melles et al., in press). Additional cores penetrating to $16 \mathrm{~m}$ sediment depth have been recently obtained (Melles et al., 2005). Because periglacial environmental changes are thought to control sediment production and subsequent transport into the lake, studying permafrost deposits (such as frozen sedimentary sequences and wedge ice and texture ice in frozen sediments) contributes to deciphering environmental dynamics in the lake catchment.

The area around El'gygytgyn Impact Crater has a variety of distinct landforms characteristically associated with permafrost 
a)

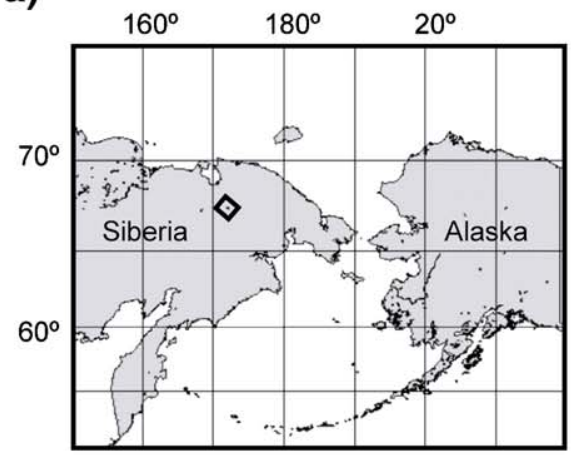

\section{b)}

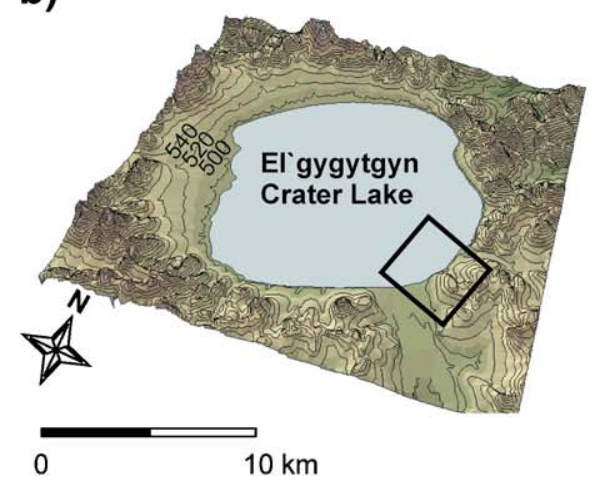

c)

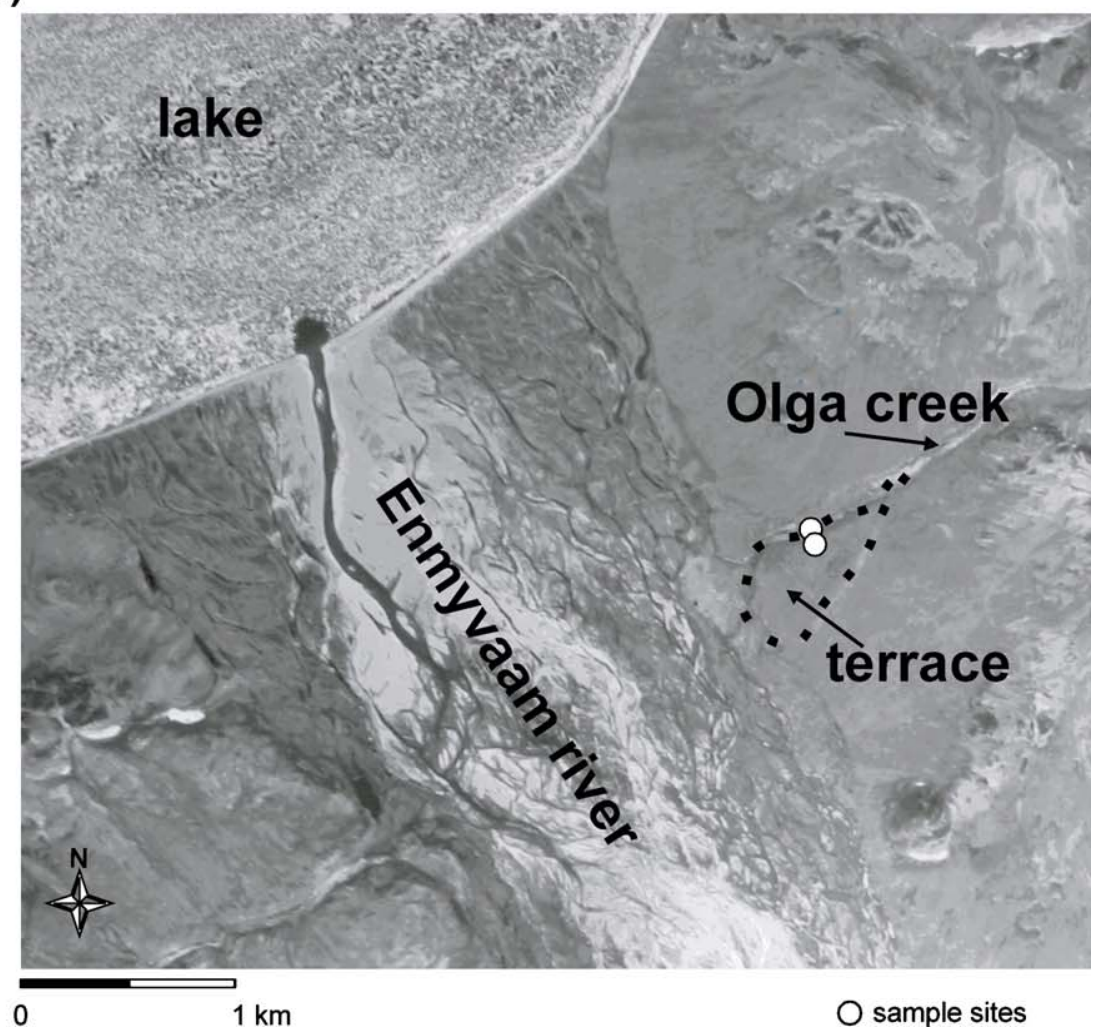

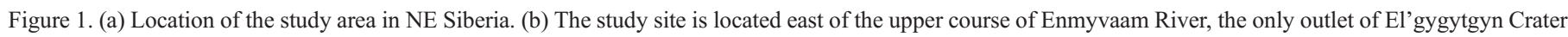
Lake, which is $495 \mathrm{~m}$ above sea level. (c) Corona-satellite image (data source: USGS) showing the location of the 5-m terrace with coring and outcrop site.

dynamics, although only some unambiguously indicate the presence of permafrost. Most conspicuous on aerial imagery are mosaics of lobes and terraces created by solifluction sheets creeping down the hillsides. Solifluction surfaces dominate the landscape cover at present (Glushkova, 2005) and probably did so throughout the Quaternary. Ice-wedge formation is the most striking periglacial feature in the area that serves as a reliable indicator of the actual presence of permafrost. It is caused by the polygonal contraction of frozen ground during winter. Repeated cracking adds new ice veins when snow meltwater permeates and subsequently freezes in the contraction cracks during spring (Lachenbruch, 1962). Polygonal networks are most distinct on lowland plains or in the foothills.

Permafrost archives can potentially be used for paleoclimate information Mackay, 1974; Burn et al., 1986; Vaikmae, 1989; Vasil'chuk and Vasil'chuk, 1997; Meyer et al., 2002a,b; Schirrmeister et al., 2003). Oxygen and hydrogen stable isotope signatures of ice-wedge transects and, though less often applied, of texture ice contained in the surrounding frozen sediments reflect changes in climatic and environmental periods Burn et al., 1986; Vaikmae, 1989). Texture ice in this study is used as a descriptive term, which includes pore ice (interstitial ice between grains) and segregated ice in the form of ice bands and ice inclusions. Quartz grain shapes and surface microtextures can be used to infer transport and depositional history from individual grains (Krinsley and Doornkamp, 1973; Elzenga et al., 1987; Mahaney, 2002; Van Hoesen and Orndorff, 2004). Whereas quartz grain features are well defined for glacial, fluvial, and aeolian sediments, comparable textures associated with mechanical damage within frozen ground have seldom been reported (e.g., Konishchev and Rogov, 1993).

The objective of this paper is to develop a sedimentation model that illustrates aggrading terrace formation at an Arctic piedmont site in late Quaternary time. The model provides basic information about slope mobility, sedimentation rates, and grain properties in continental Arctic permafrost conditions. Related permafrost dynamics are understood to initiate sediment release and final export towards basin areas like the nearby El'gygytgyn Crater Lake. They may thus serve as a helpful indicator of catchment changes that can be used in the interpretation of the lake sediment record.

\section{Study area}

A piedmont terrace was selected that is located about $1.7 \mathrm{~km}$ southeast of El'gygytgyn basin (Fig. 1 b). The altitude of Crater Lake is $495 \mathrm{~m}$ above sea level (asl) and the highest peaks forming the crater walls are about $900 \mathrm{~m}$ asl. Local basement rocks are of volcanic origin and belong to the Late Cretaceous Okhotsk-Chukotka volcanic belt Belyi, 1998; Layer, 2000; Ispolatov et al., 2004). The rocks consist largely of andesitic to rhyolitic tuffs and ignimbrites of primarily acidic composition; some subalkaline basaltic andesites have been identified framing Crater Lake to the southwest where the study site is located. The terrace emerges $5 \mathrm{~m}$ above the valley floor with the Enmyvaam River valley to the west and has a width of about 150-200 m 
(Fig. 17). A small creek (informally known as "Olga Creek") borders the northern end of the terrace and has created a steep edge, partly undercutting the overhanging sediment face. Today's slope angle at the study site is $5^{\circ}$, with exposure to the southwest. The vegetation cover of the tundra soil, at around $80 \%$, is relatively dense. Conspicuous surface drainage is only observed during spring snowmelt. The surface of the ground is mostly dry during the summer. Creeks are intermittent and ponds do not persist. The terrace is representative of widespread surfaces of similar morphology that can be found at the creek mouths of various small ephemeral streams entering the river valley. The sediment aprons entering the Enmyvaam River Valley are commonly composed of frozen, poorly consolidated, weathered debris. In 2003, the active layer was about $40 \mathrm{~cm}$ deep in peaty silts and reached 50 to $80 \mathrm{~cm}$ in sand, pebbles, and gravels. In 2002, the region had an average annual air temperature of $-10^{\circ} \mathrm{C}(3 \mathrm{~m}$ above the ground in the Enmyvaam river valley) with extremes from $-40^{\circ} \mathrm{C}$ to $+26^{\circ} \mathrm{C}$. Precipitation consisted of $70 \mathrm{~mm}$ summer rainfall (June-September) and $108 \mathrm{~mm}$ water equivalent of snowfall (Nolan and BrighamGrette, in pres\$). Humidity in 2002 ranged around $80 \%$ with extremes from $100 \%$ to $18 \%$.

\section{Methodology}

The terrace formation encompasses features of both slope deposits and ice-wedge formations (Fig. 2). Following Burn et al. (1986), we assume that the colluvial frozen sediment succession contains accumulated summer active-layer deposits, while the ice-wedge morphology and isotopic composition of enclosed ice preserve a signal of the paleo winter precipitation (Mackay, 1983; Romanovsky, 1976).

Some general considerations apply to the use of stable isotope techniques as a tool for paleoenvironmental interpretation. The ocean is the main source for atmospheric water vapor. The movement of an air mass from a moisture source towards higher latitude, altitude or distance to the sea progressively removes the heavy isotopes from the cloud. On a global scale, the $\delta \mathrm{D}$ and $\delta^{18} \mathrm{O}$ of fresh surface waters are correlated linearly in the "global meteoric water line" (GMWL). This relationship between $\delta \mathrm{D}$ and $\delta^{18} \mathrm{O}$ is due to temperature-dependent fractionation at the phase transitions of water (e.g., condensation) in the hydrological cycle and is defined as: $\delta \mathrm{D}=8 \delta^{18} \mathrm{O}+10 \%$ V-SMOW (Vienna Standard Mean Ocean Water) (Craig, 1961). In ground ice, the lowest $\delta^{18} \mathrm{O}$ and $\delta \mathrm{D}$ values are attributed to the coldest temperatures. Dansgaard (1964) introduced the deuterium excess $(d)$, giving the position relative to the GMWL in a $\delta \mathrm{D}-\delta^{18} \mathrm{O}$ diagram, defined as $d=\delta \mathrm{D}-8 \delta^{18} \mathrm{O} . d$ reflects the sensitivity of $\mathrm{H}$ and $\mathrm{O}$ isotopes to disequilibrium fractionation processes in the hydrological cycle, such as changes of humidity, wind speed or sea-surface temperature in the moisture source region (Merlivat and Jouzel, 1979).

Ice wedges are fed mainly by winter precipitation Vaikmae, 1989; Vasil'chuk, 1992), so that the water filling frost cracks is snowmelt. In contrast, texture ice formed in the active layer consists of refrozen soil water, which is a mixture of waters of various origins: summer and winter precipitation, surface waters, and last winter's ice. Repeated seasonal thawing and freezing adds numerous cycles of phase change, mixes the isotopic composition in the active layer, and generally reduces the variations of isotopic composition in texture ice. Isotopic fractionation takes place when soil water turns to ice slowly, with light isotopes crystallizing first and enriching a heavier isotope composition in the remaining soil water. In contrast, the formation of ice veins has a trend towards more negative $\delta$-values in the direction of freezing (Vaikmae, 1989).

Even though preservation of soil moisture in texture ice occurs in a complex way, it can still reflect environmental and climatic changes. Major paleoenvironmental and paleoclimatic events can be resolved by interpreting the texture ice record (Murton and French, 1994; Kotler and Burn, 2000). Studying the water cycle, however, is a precondition for this interpretation, since its complexity demands careful application in paleoenvironmental reconstruction when using stable oxygen

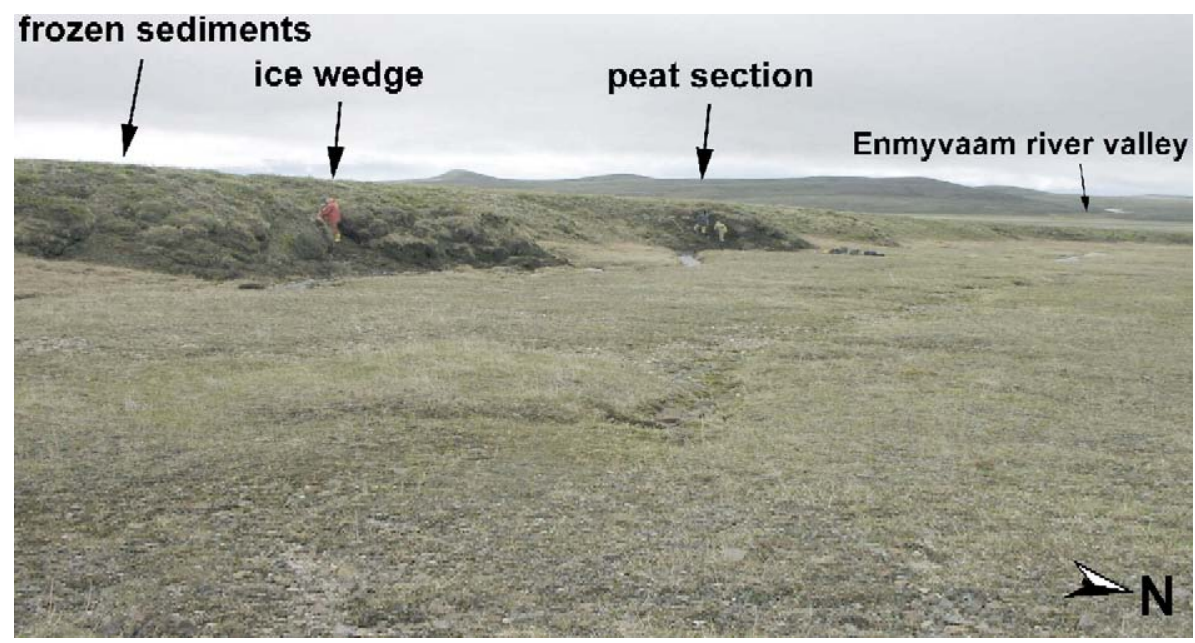

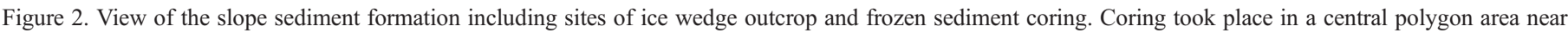

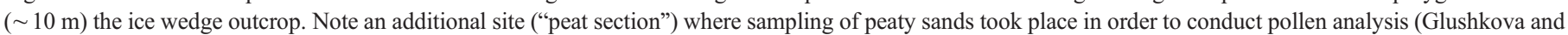
Smirnov, in press). See the text for more discussion. 
and hydrogen isotopes. Several atmospheric and terrestrial sources of $\mathrm{H}_{2} \mathrm{O}$ (snow, rain, surface waters) were collected throughout the field season (May-September 2003) to generate a minimum set of end members (ice wedges and texture ice in sediments) that have contributed to permafrost ice.

Complementary field approaches have been chosen to study the major terrace components. First, ice wedge outcrops $5 \mathrm{~m}$ in height at the northern end of the terrace were excavated, cleaned, described and sampled (Fig. 2). The ground ice was analyzed for two stable isotopes $\left(\delta^{18} \mathrm{O}, \delta \mathrm{D}\right)$, similar to glaciological applications, in order to distinguish genetic units (Dereviagin et al., 2003) and define periods of paleoclimatic change (Vasil'chuk and Vasil'chuk, 1997; Meyer et al., 2002a; Schirrmeister et al., 2002). Second, $5 \mathrm{~m}$ of frozen sediments were cored, described and likewise sampled from the center of a polygon. The coring site on the terrace was located about $10 \mathrm{~m}$ away from the ice wedge outcrop (Fig. 2). Prior to sediment sampling, ground penetrating radar (GPR) profiles were collected as a pre-survey to define the principal stratigraphic setting. Various $50-\mathrm{MHz}$ profiles using RAMAC/GPR antennae with $0.5-\mathrm{m}$ trace spacing were collected forming triangles on the hummocky tundra surface to cover the subsurface in three dimensions. The profiles were used to narrow down a location for the shallow coring of noncryoturbated layers. GPR measurements were completed by common-midpoint (CMP) measurements to deduce the electromagnetic wave velocity in the permafrost Annan and Davis, 1976). Hereafter, frozen sediment was recovered down to a depth of $502 \mathrm{~cm}$ using a 6-cm-diameter frozen ground coring kit powered by a $2.9 \mathrm{~kW}$ engine. Sampling was done in $10-\mathrm{cm}$ intervals or finer, depending on sediment change.
Field description of the sediments included grain-size composition, color, organic content, and cryotexture. Frozen samples stored in polyethylene bags were weighed, thawed, and allowed to settle. Supernatant water was extracted from the sediment samples and sub-samples were taken for stable isotope analysis $\left(\delta^{18} \mathrm{O}\right.$ and $\left.\delta \mathrm{D}\right)$ and further hydrochemical analyses. The latter were obtained using a syringe with the water filtering through a $0.45-\mu \mathrm{m}$ acetate filter (Hasholt and Hagedorn, 2000). Electrical conductivity (EC) and pH using a WTW Cond340i conductivity meter and a WTW $197 \mathrm{~N}^{\circ}$ III pH probe were measured in the field. Sub-samples were taken for analysis of the light soluble major cation content. These samples were acidified with concentrated $\mathrm{HNO}_{3}$ down to $\mathrm{pH}<2$. All samples were stored and tightly wrapped in HDPE bottles for transport to the laboratory.

Within the ice-wedge structure, several transects were sampled horizontally across the temporal axis of ice-wedge growth (Fig. 3). In addition, several samples were taken from veins of recent ice wedges. The ice was collected manually using tube-like ice screws with an inner diameter of $14 \mathrm{~mm}$. Measurements and chemical treatment of the ice-wedge samples in the field is the same as described above for the ice-rich sediment recovered in the core.

Stable isotopic measurements were made using a Finnigan MAT Delta-S mass spectrometer. They are presented using the $\delta$-notation such that $\delta$ represents the per mil relative difference of ${ }^{18} \mathrm{O} /{ }^{16} \mathrm{O}$ or $\mathrm{D} / \mathrm{H}$ in a sample with respect to the Vienna Standard Mean Ocean Water (V-SMOW). The procedure is described in Meyer et al. (2000). Internal $1 \sigma$ error is better than $0.1 \%$ and $0.8 \%$ for $\delta^{18} \mathrm{O}$ and $\delta \mathrm{D}$, respectively. Cation concentrations were determined by elemental occurrence $(\mathrm{Ca}, \mathrm{Mg}$, a)

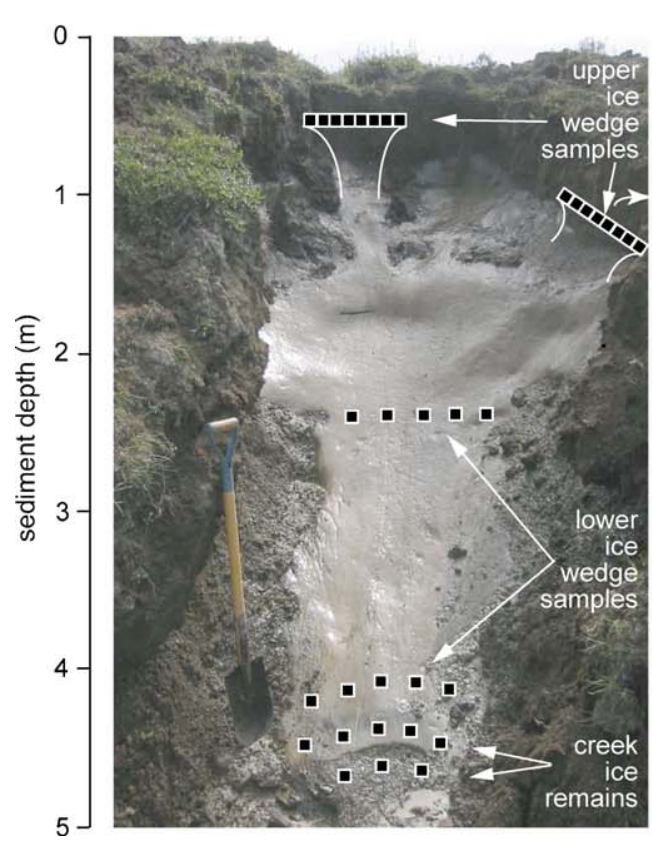

b)

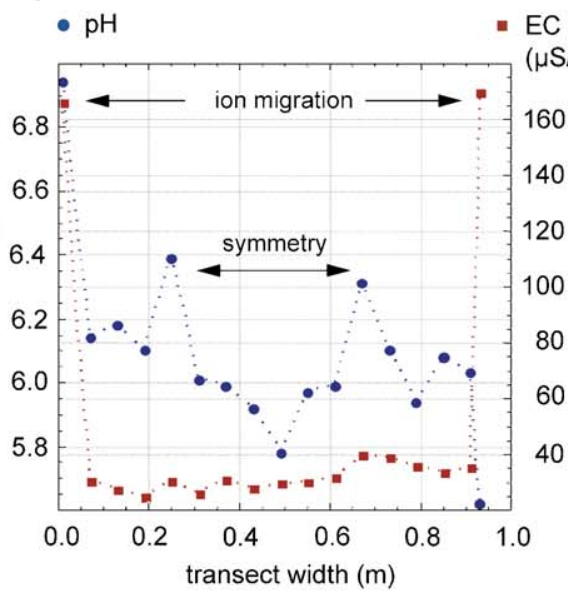

c)

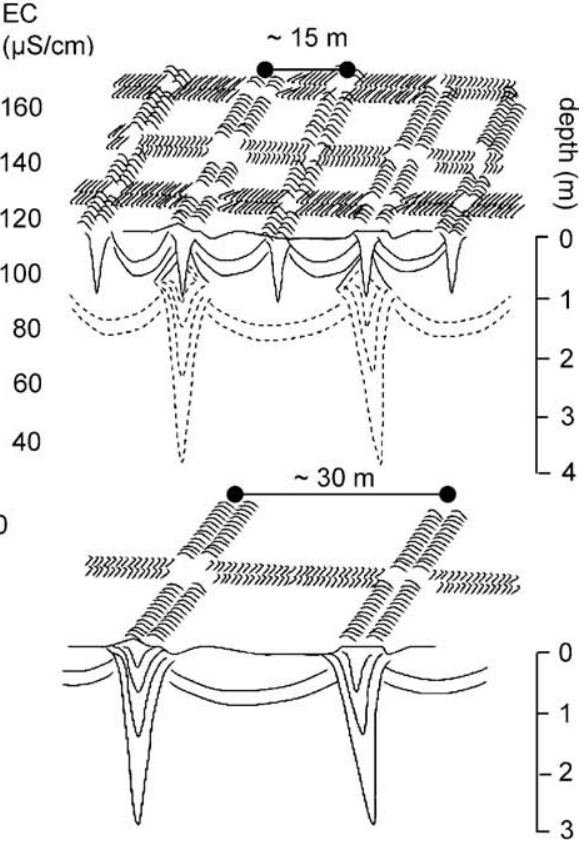

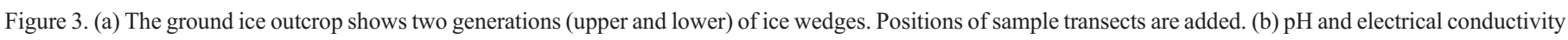

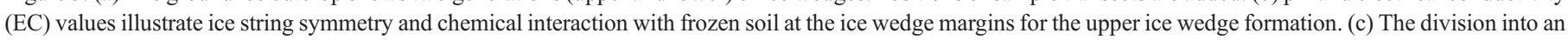
upper and lower ice wedge generation is associated with different-sized polygons. 
$\mathrm{Na}$, and K) using an ICP-OES Optima3000 XL (PerkinElmer) instrument. Ion concentrations are expressed in milli-equivalents per liter (meq/l).

After freeze-drying in the laboratory the gravimetric ice content for the sediments was determined and was expressed as total water content equivalent in weight percentage (wt.\%). Representative samples along the sediment section were selected for detailed studies of grain-size distributions in the clay-siltsand range determined by laser particle sizing (LS200, Beckman Coulter Comp.) and for scanning electron microscopy (SEM) of quartz grain shapes and microtextures in the fine sand fraction $(63-125 \mu \mathrm{m})$.

Light mineral fractions containing quartz were obtained as follows. Samples of $50 \mathrm{~g}$ were oxidized $\left(3 \% \mathrm{H}_{2} \mathrm{O}_{2}\right)$ and dispersed (concentrated $\mathrm{NH}_{4} \mathrm{OH}$ ). The heavy minerals were separated using sodium metatungstate solution $\left(\mathrm{Na}_{6}\left(\mathrm{H}_{2} \mathrm{~W}_{12} \mathrm{O}_{40}\right)\right.$ $x \mathrm{H}_{2} \mathrm{O}$ ) with a density of $2.89 \mathrm{~g} / \mathrm{cm}^{3}$ (Callahan, 1987). Samples of approximately $1-3 \mathrm{~g}$ were dispersed in the solution and centrifuged. The heavy fraction was frozen in liquid nitrogen. The light fraction was decanted and washed $10 \mathrm{~min}$ in $\mathrm{SnCl}_{2}$ $(5 \%)$ to remove iron; they were cleaned with distilled water and put in an ultrasonic bath ( $2 \mathrm{~min}$ ), and then boiled in ethanol for $5 \mathrm{~min}$ before washing again (Schirrmeister, 1995). Approximately 200 chemically cleaned quartz grains in total were selected under a binocular microscope, from which a random group of 20 to 30 grains per sample were mounted on aluminum stubs and coated with gold-palladium. The grains were examined and photographed in detail on a Carl Zeiss Germany DSM 962 scanning electron microscope.

Total organic carbon (TOC) was measured with a Vario EL III element analyzer in samples $(5 \mathrm{mg})$ that had been treated with $\mathrm{HCl}(10 \%)$ at a temperature of $80^{\circ} \mathrm{C}$ to remove carbonate. Samples were heated $\left(1150^{\circ} \mathrm{C}\right)$ and supplied with oxygen during analysis. The TOC content was measured by heat conductivity using helium as a carrier gas. International standard reference materials covering the measured range, as well as double measurements, were used to check for external precision. The following errors were accepted: $\pm 5 \%$ for TOC content $>1$ wt. $\% ; \pm 10 \%$ for TOC content $<1$ wt. $\%$. Plant remains were picked for radiocarbon dating, which was performed at the Leibniz Laboratory, University Kiel. ${ }^{14} \mathrm{C}$ ages were calibrated into calendar years before present (cal yr BP) following the method described in Stuiver et al. (1998).

\section{Results}

\section{Ice-wedge morphology}

The ice-wedge outcrop dimensions and morphology shows that the terrace contains two generations of ice wedges (Figs. 3a, c). A lower set (5.0 to $1.2 \mathrm{~m}$ below the surface, $1 \mathrm{~m}$ in width) belongs to a wider-spaced polygonal network with polygons measuring about $30 \mathrm{~m}$ in diameter. A more narrowly spaced polygon network (down to $1.2 \mathrm{~m}$ below the surface) overlies the lower set and consists of four visible individual wedges forming smaller polygonal diameters of 10 to $15 \mathrm{~m}$. The alteration in polygonal size suggests a surface temperature change in the upper sediment layers. It could be related to local changes in vegetation cover or due to thickness changes of snow cover (Romanovsky, 1973). Individual ice veins in the two polygonal networks are white and grayish in color, depending on the amount of vertically aligned air bubbles. A straight white line resulting from a recent cracking runs down from the top to the bottom of the whole ice-wedge outcrop. The west side of the ice wedge, in particular, is composed of centimeter- to decimeter-sized angular clasts. The original stratigraphy has been transformed to a more chaotic sedimentary structure. One decimeter from the ice wedge, the regular sedimentary layering can be observed. The angular clasts presumably stem from underlying frost-jacked rocks and sediment displacement from lower positions upwards provide evidence for epigenetic ice-wedge growth (Romanovsky, 1973). A horizontal $\mathrm{pH}$ profile in the upper ice wedges shows quasisymmetrical growth (Fig. 3b). High electrical conductivities in melted ice samples from the ice wedge margins suggest active migration processes from the surrounding sediments. These chemically modified samples have been excluded from the stable isotope interpretations discussed below.

\section{GPR section}

A GPR profile example displays the typical appearance of reflection results in hummocky tundra terrain containing ice wedges (Fig. 4). The low-frequency antennas used (50 MHz) yielded reflections down to $200 \mathrm{~ns}$ two-way travel time. Above the coring position a CMP-deduced wave velocity in the ground was determined at $0.13 \mathrm{~m} / \mathrm{ns}$. Two-way travel times thus convert to a maximum electromagnetic penetration of approximately $8 \mathrm{~m}$. This value is valid for frozen sediments only. From field control it was obvious that sites with concave reflectors point to ice wedge bodies whereas regular horizontal to slightly convex reflectors represent the sediment layering in central polygonal areas. Reflector layering within the ice wedges is not natural but results from oblique reflections and diffractions from near vertical boundaries between the sediments and ice. This unfortunately masks the contact between the ice wedge bottoms and the ground underneath so that proportions cannot be estimated accurately at depth (Hinkel et al., 2001; Fortier and Allard, 2004). Subsequent focus was placed on the central area of a polygon field where curved layers resulting from cryoturbation could be avoided and a site showing strong horizontal reflectors was selected for sediment studies.

\section{Sediment substrate and ages}

The macroscopic features of a frozen core extracted down to $5.0 \mathrm{~m}$ sediment depth show that the terrace substrate is generally composed of a diamicton dominated by sand and silt (Fig. 5). Pebble-sized subangular clasts occur mainly in the lower core and decrease in number towards the top. Two prominent peaty interlayers interrupt the section at $3.05-2.75 \mathrm{~m}$ and $2.40-2.35 \mathrm{~m}$ sediment depth. More plant remains are scattered along the core, especially in the upper part. Organic matter dating of plant remains revealed a regular age-to-depth relationship with 


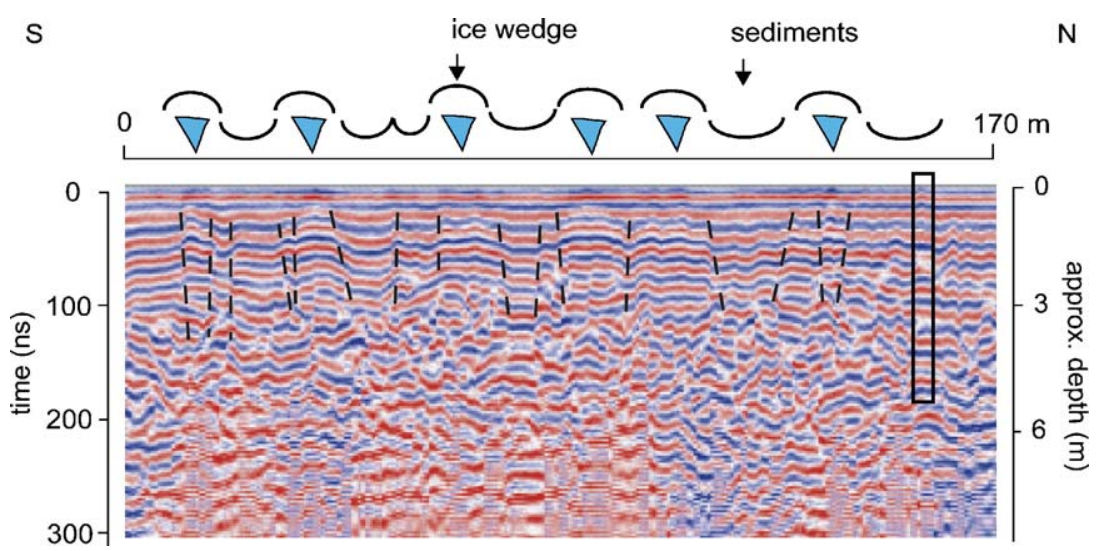

Figure 4. Example of a $50 \mathrm{MHz}$ GPR profile recorded in frozen polygonal ground. The alternation of concave/convex shaped features is associated with ice-wedge bodies and intra-polygonal sediments. The rectangle marks the position of the permafrost core.

extrapolated ages reaching down to almost $14,000 \mathrm{cal}$ yr BP for the lowermost sediments (Table 1). Inferred sedimentation rates show that except for the peaty interlayers they are fairly constant, ranging between 0.04 and $0.08 \mathrm{~cm} / \mathrm{yr}$ (Fig. 5). Sedimentation, though, has clearly been slowing down during the last $3000 \mathrm{yr}$, generating only $0.4 \mathrm{~m}$ of sediment in that time.

Ice content and texture varies between layers or within layers. They contain low amount of interstitial to reticulated ice (especially at 5.0 to $3.0 \mathrm{~m}$ sediment depth) or high ice contents made up of lenses or discrete cm-thick layers of ice (especially at 2.0 to $1.0 \mathrm{~m}$ sediment depth). Two genetic mechanisms must be considered for the latter type: either segregation processes formed the ice layers and inclusions, or else high summer rainfall has been preserved in the lower part of the active layer during sediment accumulation at the polygon centers Mackay, 1983).

\section{Sediment stratigraphy}

The lower core (5.0 to $3.2 \mathrm{~m}$ sediment depth) contains considerable amounts of clay (up to $20 \%$ ), followed by a middle part (3.2 to $2.1 \mathrm{~m}$ sediment depth) where sand dominates, and an upper part (2.1 to $0.0 \mathrm{~m}$ sediment depth) that has higher silt portions (Fig. 6). The sand-dominated middle core corresponds to what has previously been interpreted as alluvial sand (Glushkova and Smirnov, in press). The corresponding sediments were sampled for pollen analysis near $(\sim 50 \mathrm{~m})$ the permafrost coring location (Fig. 2). Variations in TOC content with

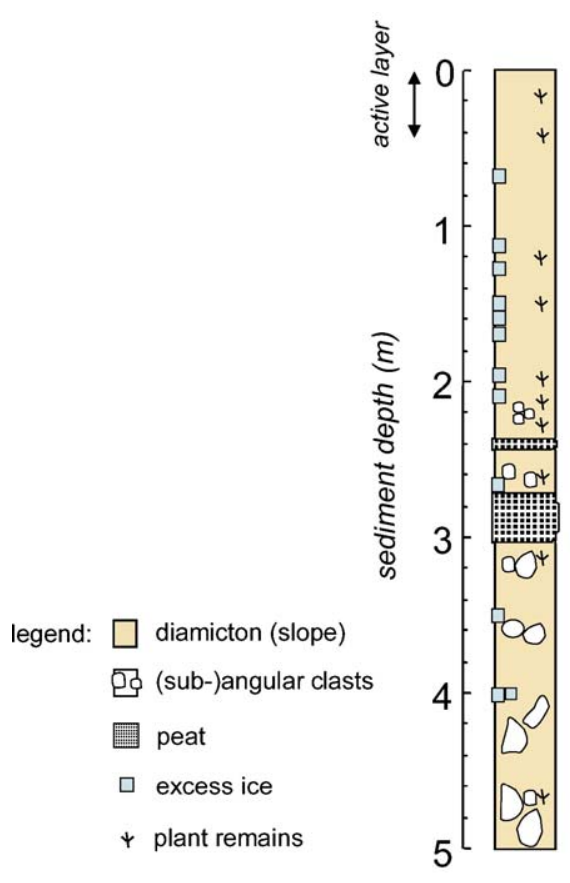

sediment ages:

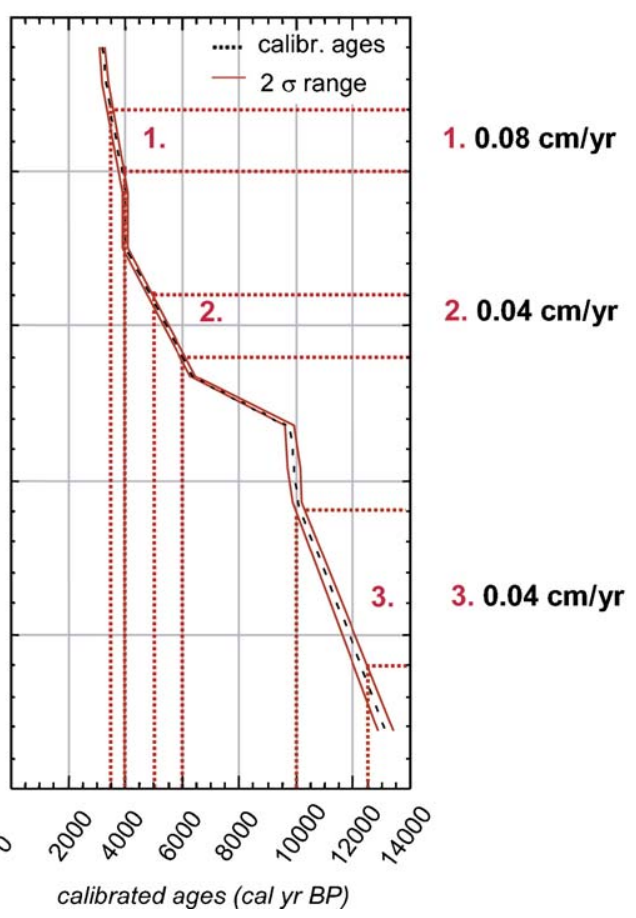

Figure 5. Macro features of the cored sediments and age model with calibrated radiocarbon ages and inferred sedimentation rates. 
Table 1

Age determinations of cored permafrost sediments with respect to AD 1950

\begin{tabular}{lccccc}
\hline $\begin{array}{l}\text { Depth } \\
{[\mathrm{m}]}\end{array}$ & $\begin{array}{l}\text { Radiocarbon age } \\
{\left[{ }^{14} \mathrm{C} \mathrm{yr} \mathrm{BP}\right]}\end{array}$ & $\begin{array}{l}2 \sigma_{1} \\
{[\mathrm{cal} \mathrm{yr} \mathrm{BP}]}\end{array}$ & $\begin{array}{l}2 \sigma_{2} \\
{[\mathrm{cal} \mathrm{yr} \mathrm{BP}]}\end{array}$ & $\begin{array}{l}\text { Calendar age } \\
{[\mathrm{cal} \mathrm{yr} \mathrm{BP}]}\end{array}$ & \begin{tabular}{l} 
Lab. no. \\
\hline 0.20
\end{tabular} \\
\hline $3000 \pm 30$ & 3097 & 3268 & 3183 & KIA25979 \\
0.43 & $3095 \pm 45$ & 3207 & 3399 & 3303 & KIA25980 \\
1.14 & $3670 \pm 30$ & 3898 & 4089 & 3994 & KIA23976 \\
1.50 & $3665 \pm 35$ & 3888 & 4090 & 3989 & KIA25981 \\
2.07 & $8145 \pm 45$ & 9011 & 9148 & 9080 & KIA28241 \\
2.33 & $5585 \pm 40$ & 6295 & 6443 & 6369 & KIA23977 \\
2.65 & $8760 \pm 45$ & 9600 & 9915 & 9758 & KIA23978 \\
2.92 & $8830 \pm 55$ & 9692 & 10,155 & 9924 & KIA23979 \\
3.14 & $8885 \pm 40$ & 9890 & 10,183 & 10,037 & KIA24865 \\
3.25 & $8920 \pm 110$ & 9680 & 10,246 & 9963 & KIA28242 \\
4.63 & $11,160 \pm 70$ & 12,893 & 13,423 & 13,158 & KIA23980 \\
\hline
\end{tabular}

$2 \sigma$-range provides $<95 \%$ probability.

depth generally parallel the sand fraction; high amounts of sand (up to $70 \%$ ) have high TOC (up to 25 wt.\%). Greatest values for both properties are seen within the peaty layer at about $2.8 \mathrm{~m}$ sediment depth. It is remarkable that sediments are free of organic material in the lower part of the core. This is associated with slope sedimentation predominantly resulting from gravitational downhill movement. The silt-dominated upper part, in contrast, argues for intense cryogenic weathering and disintegration of particles, especially of quartz grains (Konishchev and Rogov, 1993). The ice content increases from the bottom (20-40 wt.\%) towards the upper core (60-75 wt.\%). This trend is pronounced and high amounts of excess ice were found in the upper core $(<2 \mathrm{~m}$ sediment depth) even though it excludes the current seasonally thawing soil $(<0.50 \mathrm{~m}$ sediment depth). According to the GPR data, the ice-rich and organic-rich horizons at $0.4 \mathrm{~m}, 1.2 \mathrm{~m}$ and $2.75 \mathrm{~m}$ sediment depth are most probably related to prominent reflections. They are also paralleled by abrupt changes in the siltto-sand ratio. However, no further sediment-to-signal comparisons have been made and the GPR profile is used here to indicate the general stratigraphic setting.

\section{Grain characteristics}

The depositional situation of a piedmont terrace in permafrost terrain seems to exclude major influences other than hill creep, short-distance alluvial transport, and active-layer dynamics from the sedimentation process. The active-layer dynamics imply that

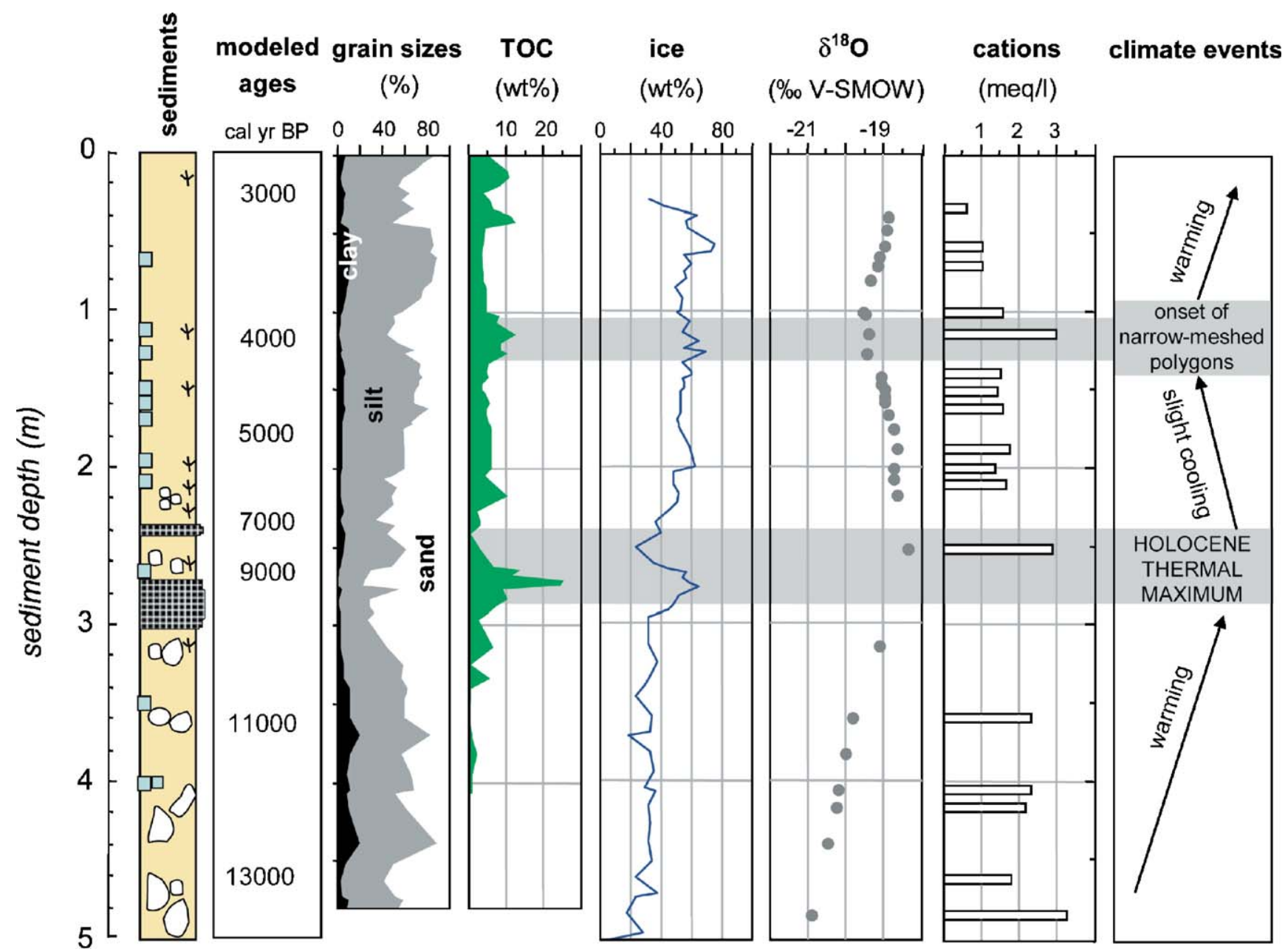

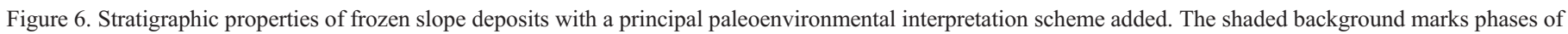
major environmental change. 
a) grain morphology
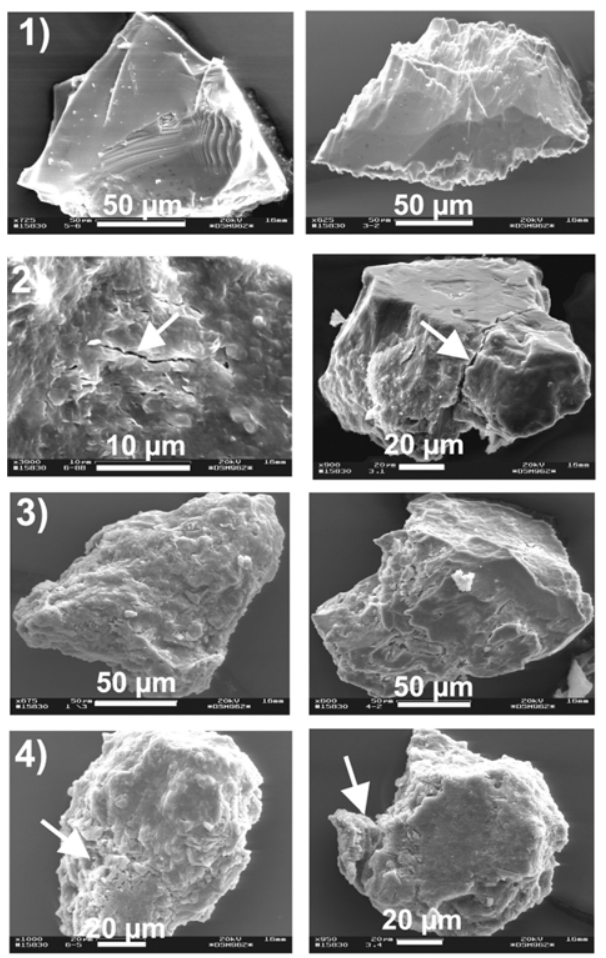

b) grain features

c) grain surface textures

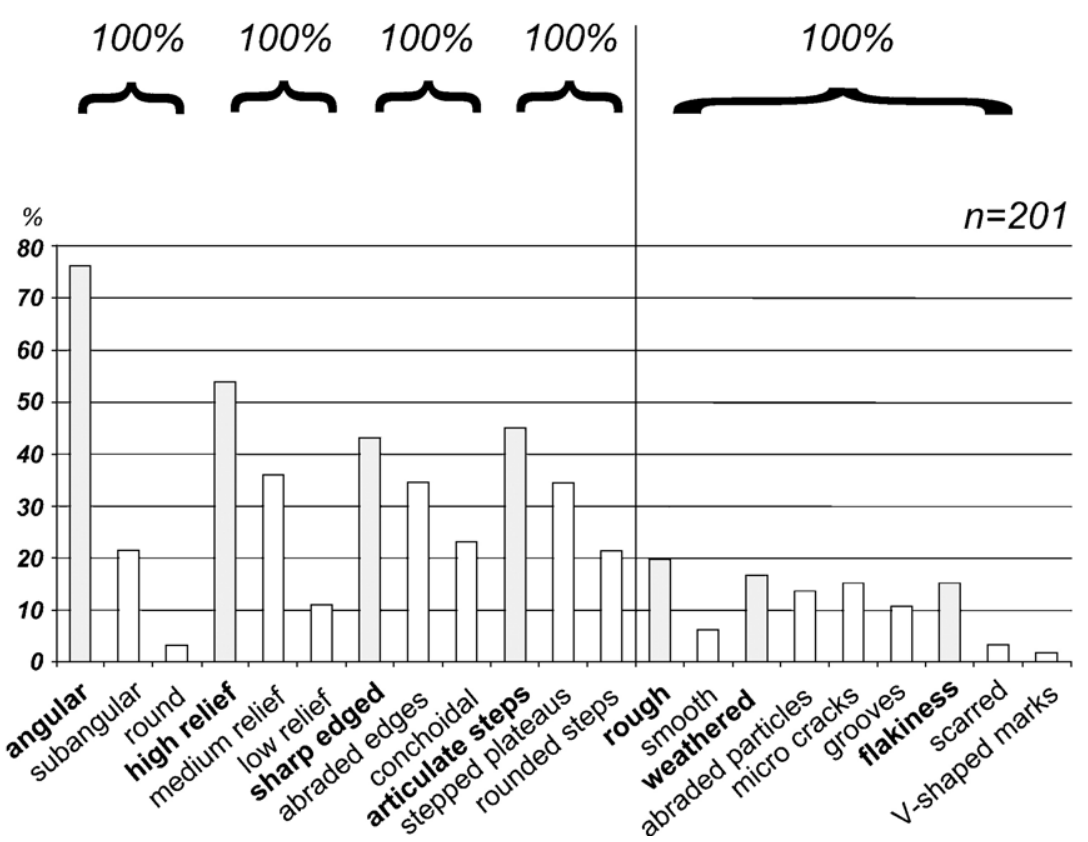

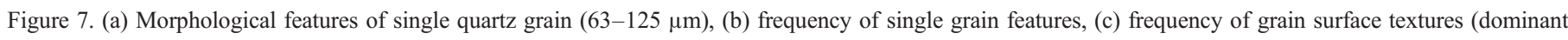

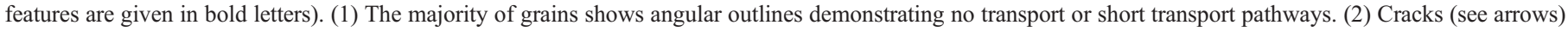
form due to cryogenic widening. (3) Frost-weathered quartz grains exhibit softened areas acting as source areas for silt particles (4, see arrows).

particles are subject to disintegration due to their considerable residence time in freeze and thaw cycles therein. Single samples from each meter interval along the core were taken and their microscopic characteristics resulted in the identification of 21 grain shape and grain surface features (Fig. 7). Angular outlines and microfeatures such as high relief, sharp edges, and articulate steps are most common and were consistently observed for all samples. This suggests short transport distances from their source rocks. Many grains are characterized by rough and weathered surfaces. Flakiness and microcracks are also common features. The grain surface textures appear particularly diagnostic for frozen-ground sediments, since their production can be directly linked to the destructive effect of thaw-freeze alternation. Frost weathered surfaces and cryogenic cracking point to the sandy grains as the source areas of silt particles. This highlights in-situ disintegration, especially of quartz grains, after they were subject to thaw-freeze dynamics Konishchev and Rogov, 1993).

\section{Stable isotope signatures: modern precipitation}

The isotopic composition of modern precipitation serves as the basis for applying paleoclimatic interpretations from the stable isotope composition in the sampled ground ice. Modern precipitation shows typical differences between snow and rain, as has been observed in northern Siberia (Meyer et al., 2002a, b; Sugimoto et al., 2003; Kurita et al., 2004). Whereas values for snow show a mean $\delta^{18} \mathrm{O}$ of $-19.9 \%$, a mean $\delta \mathrm{D}$ of $-153 \%$ and cluster along the GMWL ( $d$ excess $=6.3 \%$ ), there is enrichment in heavy water isotopes in modern rain samples $\left(\delta^{18} \mathrm{O}=-14.6 \% ; \delta \mathrm{D}=-122 \%\right.$ ) (Table 2). These rain values show a distinct offset from the GMWL ( $d$ excess $=-4.8 \%$, Fig. 8). Thus, snow appears to carry a nearly unaltered precipitation signal from the original moisture source, but rain shows a clear kinetic fractionation of isotopes. Drier air masses may have interacted with the moisture during rainfall, or water originating from the Siberian land surface may be included. This may be related to interaction with dry air masses during rainfall or to the participation of reprecipitated moisture derived from recycled water masses from the Siberian land surface and with several evaporation cycles possibly included (Kurita et al., 2003; Sugimoto et al., 2003). The El'gygytgyn Crater mean contains samples of (1) fresh summer snow and (2) snow patches, which are remains of the previous winter snowfall. This

Table 2

Mean values $\left(\delta^{18} \mathrm{O}, \delta \mathrm{D}, d\right.$ excess) for $\mathrm{H}_{2} \mathrm{O}$ sample sets

\begin{tabular}{lllc}
\hline $\mathrm{H}_{2} \mathrm{O}$ sample sets & $\delta^{18} \mathrm{O}(\%$ V-SMOW) & $\delta \mathrm{D}(\%$ V-SMOW) & $d$ excess \\
\hline Snow & -19.86 & -152.7 & 6.3 \\
Rain & -14.64 & -121.9 & -4.8 \\
Surface water & -21.32 & -163.1 & 7.5 \\
Surface ice & -18.52 & -146.3 & 1.8 \\
Remains of creek ice & -19.21 & -146.2 & 7.5 \\
Modern ice veins & -20.40 & -155.0 & 8.2 \\
Upper ice wedge set & -22.36 & -169.8 & 9.1 \\
Lower ice wedge set & -23.54 & -179.7 & 8.6 \\
Texture ice & -19.31 & -147.8 & 6.7 \\
\hline
\end{tabular}




\section{$\delta^{18} \mathrm{O}(\%)$ V-SMOW}

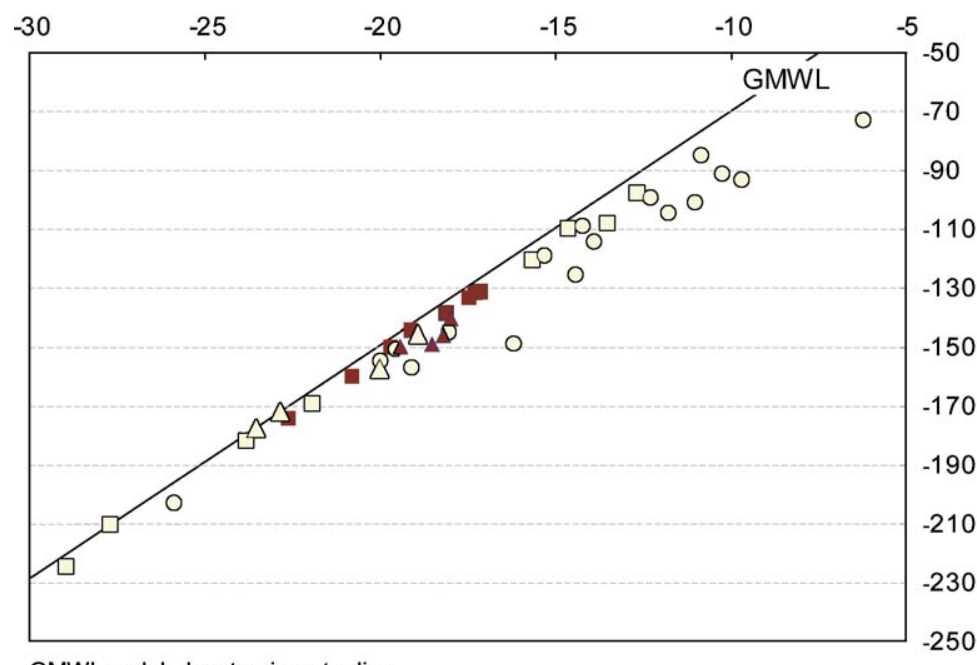

\begin{tabular}{|c|c|}
\hline & $\begin{array}{l}\text { modern precipitation and } \\
\text { surface water: }\end{array}$ \\
\hline & $\square$ snow \\
\hline & o rain \\
\hline วิ & $\Delta$ surface water (creeks, ponds) \\
\hline 0 & $\Delta$ lake ice \\
\hline & creek ice remains \\
\hline
\end{tabular}

GMWL = global meteoric water line

Figure $8 . \delta^{18} \mathrm{O} / \delta \mathrm{D}$ bi-plot of $\mathrm{H}_{2} \mathrm{O}$ samples from modern precipitation, surface waters, and ice.

explains the great range of isotopic values, e.g. from $\delta^{18} \mathrm{O}-12$ to $-29 \%$. Snow patches show light isotopic composition and a $d$ excess around $9.5 \%$, interpreted to result from winter snow, whereas summer snow shows heavier $\delta^{18} \mathrm{O}$ and $\delta \mathrm{D}$ and a deviation from the GMWL towards lower $d$ excess (similar to summer precipitation). Relatively heavy compositions are also found from two sample transects at the bottom of the outcrop ("remains of creek ice" in Fig. 3a). Means of $\delta^{18} \mathrm{O}=-19.2 \%$ o and $\delta \mathrm{D}=-146.2 \%$ (Table 2) are too heavy to result from icewedge growth. Instead, this ice overlaps with surface waters from creeks, ponds and lake ice, respectively. The basal ice at the ice-wedge outcrop is therefore interpreted to derive from frozen creek waters of previous winters.
Stable isotope signatures: ice wedges

The mean isotopic compositions of snow and modern ice wedges are very similar (Table 2). The modern ice veins show a mean $\delta^{18} \mathrm{O}$ of $-20.4 \%$, $\delta \mathrm{D}$ of $-155 \%$, and a $d$ excess of $8.2 \%$. This confirms a close genetic relationship between the two, although modern ice wedges have a slightly lighter isotopic composition. This may be due to an overestimate of the proportion of summer snow for the calculation of the mean snow value. Summer snow is not relevant for the formation of ice wedges, since first melt water in spring generally fills the frost cracks. Stable isotope measurements of the sampled ice wedges also confirm the genetic relationship between the

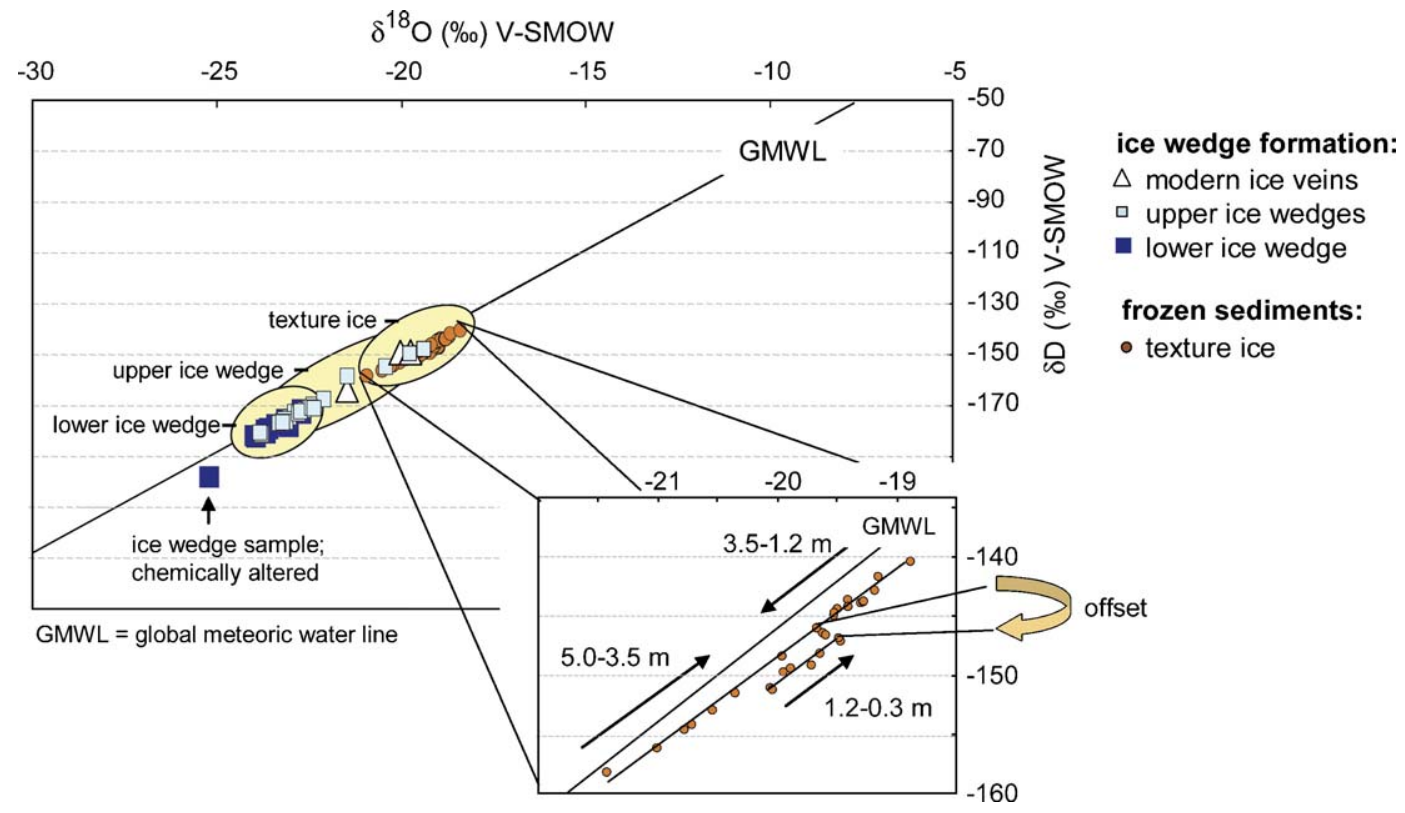

Figure 9. $\delta^{18} \mathrm{O} / \delta \mathrm{D}$ bi-plot of $\mathrm{H}_{2} \mathrm{O}$ samples from ground ice (ice wedges and texture ice). 
bottom ice wedge and the top ice wedges, respectively. The stable isotope values from both bottom and top sets differ to a small extent and both are positioned close to the GMWL. The lower generation (5.0-1.2 m sediment depth) has mean values of $\delta^{18} \mathrm{O}=-23.5 \%, \delta \mathrm{D}=-180 \%$, and $d$ excess $=8.6 \%$ whereas the upper generation $(0.0-1.2 \mathrm{~m}$ sediment depth) has mean isotopic composition of $\delta^{18} \mathrm{O}=-22.4 \%, \delta \mathrm{D}=-170 \%$, and $d$ excess $=9.1 \%$ (Fig. 9). This trend towards more positive values is continued in the modern ice veins (see above). This is taken as an indication that there is a slight warming of winter temperatures associated with the transition from the lower to the upper generation and to the modern ice veins preserved during ice-wedge formation. It is remarkable that the heaviest isotopic signatures and, thus, warmest winter temperatures are related to the modern ice wedges. This phenomenon is also observed in other locations in northern Siberia Meyer et al. 2002b). Overall, ice-wedge values are close to the winter precipitation signal $\left(\delta^{18} \mathrm{O}=-23.4 \% ; \delta \mathrm{D}=179 \%\right)$, arguing for weak fractionation of isotopes, i.e. during refreezing of meltwater (Michel, 1982). The nearly unaltered precipitation signal from the original moisture entering frost cracks seems to have been persistent throughout the time of El'gygytgyn icewedge formation. Pleistocene-aged ice wedges elsewhere in northern Siberia have been found to display a considerably lighter stable isotope composition Vasil'chuk, 1992; Meyer et al., 2002a,b; Schirrmeister et al., 2002; Popp et al., in press). The absence of lighter stable isotope signatures at the study site thus demonstrates a strictly Holocene age of all sampled ice wedges.

\section{Stable isotope signatures: Texture ice}

As mentioned earlier, texture ice within terrace sediments results from pore ice or occasionally from ice layers embedded in the frozen sediments. Single ice layers could result from segregation processes. Since different processes might be responsible for the formation of pore ice and segregated ice, the texture ice isotope data was checked for abrupt variations that might point to different ice geneses. However, variations of texture ice values are generally small whether they result from pore ice or from ice lenses. No sudden deviations were observed in the isotope curve of texture ice (Fig. 6). Consequently, a similar process, most likely syngenetic ice formation, is assumed to have led to the formation of both types of ice.

The mean isotope composition of the texture ice (mean $\delta^{18} \mathrm{O}=-19.3 \% ; \delta \mathrm{D}=-148 \%$, $d$ excess $=6.7 \%$ ) (Table 2) is slightly shifted towards heavier values when compared with the ice-wedge clusters (Fig. 9). Furthermore, it overlaps with the isotopic composition of the surface water (creeks, ponds) and is located between the mean isotopic composition of snow and rain (Fig. 8). Thus, it may reflect a mixture evolved from snow and rain integration, even though the mean values are closer to the snow signature mean. Assuming texture ice as a two-component mixture between snow and rain with the mean snow and mean rain isotopic composition as the two end members, the relative proportions would be $89 \%$ snow and $11 \%$ rain when using $\delta^{18} \mathrm{O}$; if using $\delta \mathrm{D}$ for the mixing cal- culations, $84 \%$ snow and $16 \%$ rain. Since the mean $d$ excess of texture ice is not between that of snow and rain, it must be taken into account that summer snow might be over-represented and winter snow underestimated in the mixing calculations. Nonetheless, winter precipitation seems to have a major influence on the formation of texture ice at this site, since the $d$ excess of texture ice is in the same range as for snow. In general, the isotopic composition of texture ice varies in a narrow range within $1 \%$ in $\delta^{18} \mathrm{O}$ (excepting the portion below $3 \mathrm{~m}$ sediment depth). This points to a well-mixed reservoir and to general similarities in the formation process, temperatures, proportions of snow and rain, moisture sources, and the freezing process through time.

Isotope fractionation during freezing must be considered for texture ice, whereas for ice wedges the freezing process is fast enough to avoid isotope fractionation. Fractionation during (slow) freezing (1) would be accompanied by a shift in the isotopic composition towards heavier values in the direction of the freezing front, which may reach up to 3\% in $\delta^{18} \mathrm{O}$ (Souchez and Jouzel, 1984; Vaikmae, 1991), but (2) should also be noticeable in the $d$ excess, because the freezing occurs along a slope in the $\delta^{18} \mathrm{O} / \delta \mathrm{D}$ bi-plot different from the one of the global meteoric water line (GMWL in Fig. 9) (much smaller than 8). All samples of texture ice are linearly correlated in the $\delta^{18} \mathrm{O} / \delta \mathrm{D}$ bi-plot with a slope of 7.3 and an intercept of $-7.6\left(\mathrm{R}^{2}=0.95\right)$, and with single $d$ excess values between $5 \%$ and $9 \%$. Consequently, fractionation during freezing cannot be ruled out but is not necessary to explain the isotopic composition of texture ice. Both slope and $d$ excess could also be explained by a mixture of much (winter) snow and little rain.

From the $\delta^{18} \mathrm{O} / \delta \mathrm{D}$ bi-plot, the relevant values (Fig. 9) are relatively close to the GMWL (mean $d$ excess around 7.5\%) for the core segment between 5.0 and $1.2 \mathrm{~m}$ sediment depth. The wider-meshed polygonal network characterizes this lower segment. The $\delta^{18} \mathrm{O} / \delta \mathrm{D}$ bi-plot (Fig. 9, inset) reveals that there is a distinct offset from the GMWL for the upper $1.2 \mathrm{~m}$ sediment depth (with a mean $d$ excess around 5\%). Obviously, these values correspond to the second, narrow-meshed ice wedge generation. This shift in the $d$ excess could be related to several processes, such as (1) a change in the moisture source, (2) different proportions of winter and summer precipitation, (3) different humidity in the area of precipitation, or (4) a higher amount of recycled water. The fact that the polygon type changes from a wider to a more narrow size points to a thermal change in the uppermost sediment layers (Romanovsky, 1973), probably related to winter warming.

\section{Stable isotopes and light soluble cations in the sediment core}

The oxygen isotope curve varies systematically along the core (Fig. 6) in a fashion very similar to other regional north Siberian climate curves. A maximum $\left(\delta^{18} \mathrm{O}=-18.5 \%\right)$ at $2.6 \mathrm{~m}$ sediment depth faces precedes a relative minimum $\left(\delta^{18} \mathrm{O}=-19.5 \%\right)$ at $1.2 \mathrm{~m}$ sediment depth. The lightest isotope composition is found in the lower part of the core $\left(\delta^{18} \mathrm{O}=\right.$ $-21 \%$ below $3.6 \mathrm{~m}$ depth), the uppermost core has heavier 
values $\left(\delta^{18} \mathrm{O}=-18.8 \%\right.$ ). The inflection points occur at sediment layers interpreted to result from stable surface conditions. The maximum corresponds approximately to a peat layer dated at the top at $9760 \mathrm{cal} \mathrm{yr} \mathrm{BP} \mathrm{(2.65} \mathrm{m} \mathrm{sediment} \mathrm{depth,} \mathrm{Table} \mathrm{1)}$ and has itself a modeled age of $9000 \mathrm{cal} \mathrm{yr}$ BP. The relative minimum is related to the top of the lower ice wedge generation with a modeled age of $4000 \mathrm{cal}$ yr BP (3994 cal yr BP at $1.14 \mathrm{~m}$ sediment depth, Table 1). The $9000 \mathrm{cal} \mathrm{yr} \mathrm{BP} \mathrm{event} \mathrm{is} \mathrm{regarded}$ as representing the regional Holocene thermal maximum (HTM) in the area. The increase in $\delta^{18} \mathrm{O}$ after $4000 \mathrm{cal}$ yr BP coincides with the transition from the lower to the upper ice wedge generation and the trend towards heavier $\delta^{18} \mathrm{O}$ values in the ice wedges. Since both ice wedges and texture ice, to a large extent, reflect winter conditions, a similar trend in the isotope curves is a logical consequence. The two prominent maximum and minimum points of the $\delta^{18} \mathrm{O}$ curve are associated with high amounts of cations, as are the lowermost core parts. Cation contents in the texture ice generally range from more than $3 \mathrm{meq} / 1$ to less than $1 \mathrm{meq} / \mathrm{l}$. The lower core samples especially have high contents, whereas the upper core samples $(<2.2 \mathrm{~m}$ sediment depth) have decreasing values. One discrete exception occurs at $1.15 \mathrm{~m}$ sediment depth, with a value as high as $3 \mathrm{meq} / \mathrm{l}$ that correlates with the relative minimum $\delta^{18} \mathrm{O}$ value and the onset of the upper ice wedge generation. Cryogenic breakup of grains in permafrost increases the amount of mineral surface, which are then subject to chemical weathering (Konishchev and Rogov, 1993). Stable soils might have supported an increasing mineralization of soil moisture due to increased cryogenic activity or to chemical weathering. The coexistence of cation maxima with minima and maxima in the isotope curve would signify that no significant post-depositional moisture transport took place in the texture ice after its formation, and it documents that the slope formation preserves the original hydrochemical signals.

\section{Discussion}

\section{Paleoclimate and paleoenvironmental signals}

The HTM signal occurs Arctic-wide; from Beringia to the east (Canada, Greenland, Iceland) a complicated spatialtemporal pattern of the HTM has been detected, which lasted anywhere 1000 to $5000 \mathrm{yr}$ in different regions and shifted over several millennia in the Holocene (Kaufman et al., 2004). The oldest HTM locations are in western Beringian (i.e. East Siberia) with some documented as old as $14.000 \mathrm{cal}$ yr BP. The youngest, in contrast, appears in the Canadian Archipelago with ages as young as 2000 to $1000 \mathrm{cal} \mathrm{yr} \mathrm{BP}$. Results from northern Yakutian lake sediments show a similar timing (Pisaric et al., 2001; Andreev et al., 2004) to what is seen in the El'gygytgyn permafrost section. Conclusions from two different bioindicators taken from other El'gygytgyn records show a noticeable conformity with the permafrost record. Increased annual temperatures were deduced from pollen analysis of samples

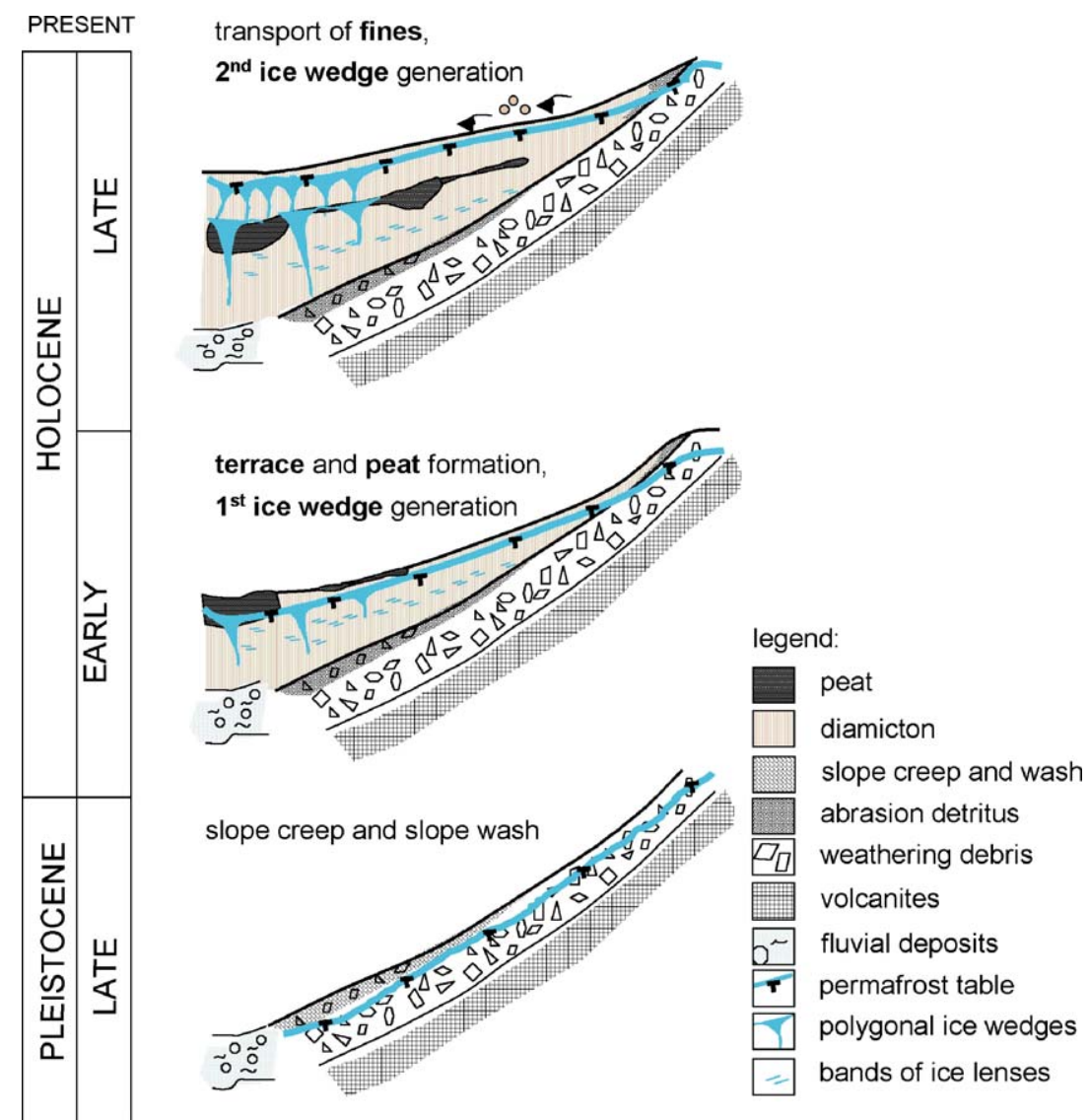


from a nearby sandy peat profile (see Fig. 2 Glushkova et al., 1999). An early Holocene treeline migration into the area has been inferred, which is expressed in biotopes of birch and alder. By the end of the Boreal period those trees vanished and were replaced by dwarf pines, indicating decreasing temperatures and increasing snow cover. This fits the postulate of a higher snow portion imported into the texture ice at the relevant core part and/ or decreasing winter temperatures. Diatom associations from a short sediment core of El'gygytgyn Lake covering the last $6000-7000$ yr demonstrate that at about $3300{ }^{14} \mathrm{C}$ yr BP $(\sim 3600 \mathrm{cal}$ yr BP$)$, summers became warmer again with longer ice-free seasons in the lake and higher bioproductivity Cremer and Wagner, 2003). This coincides with the transition from the lower to the upper ice wedge generation and the trend towards heavier $\delta^{18} \mathrm{O}$ values in the ice wedges as well as in texture ice. The pollen record in El'gygytgyn lake sediments only holds a regional vegetation signal, in which the local onset of HTM (Shilo et al., 2001; Melles et al., in press) is not particularly pronounced.

Stable surface conditions led to enrichment of cations in the soil layers, i.e. the (paleo-) active layers at the inflection points. The enrichments preserved at $2.5 \mathrm{~m}$ and $1.15 \mathrm{~m}$ sediment depth may have been created when ionic migration took place during freeze-back of the active layer in late autumn. Along the freezing fronts from above and below the remaining supersaturated solutions freezes at last Qui et al., 1988; Ostroumov et al., 2001). Cation enrichment is promoted by repeated freeze-thaw cycles in the same active layer and its preservation in the paleo record would argue for no considerable post-depositional moisture transport into the active layer. Instead, increased cryogenic activity promoted frost cracking of grains. Generally, cold periods result in greater physical weathering as usual for late Pleistocene times (Konishchev and Rogov, 1993). This may add mineral surfaces exposed to geochemical weathering and is suggested to be the explanation for the high cation concentrations in the lower part of the core.

\section{Sedimentation model}

The terrace originated and accumulated from abrasion and weathering debris of late Pleistocene age (Late Sartanian or Younger Dryas). As the terrace emerged from the Enmyvaam River valley, climatic conditions created permafrost in the deposits (Fig. 10). Ice-wedge networks presumably began to grow, starting from frost fissures on the slope surfaces. Considerable amounts of pebble-sized angular clasts and clay characterize this early period of slope sediment deposition. Higher TOC contents suggest an increased soil cover and coincide with the transition to the Holocene. Warming in the early Holocene led to the formation of peat and a stable, cryogenically active surface that retarded further sediment accumulation at the site for a while. Increased sand portions indicate either a phase of significant alluvial or flood plain deposition. Throughout the Boreal period towards the late Holocene time, temperatures decreased and snowfall increased, which led to the creation of a second, narrow-meshed polygon generation in thermally altered surface deposits. Since then, the climate has changed to warmer annual temperatures, again expressed in heavier stable isotope compositions in both ice wedges as well as in sedimentary texture ice. The proportion of summer rain has increased relative to snow since $3300 \mathrm{cal}$ yr BP. Alternatively, recycled water from El'gygytgyn Lake when it had longer open-water periods in summer may have acted as an additional source for moisture preserved as sedimentary texture ice in the area. Simultaneously, sedimentation rates decreased considerably to half that of earlier times. Whether or not this is a signal of increased atmospheric aridity in the area or the result of decreased slope angles cannot be explained at this stage. A growing fraction of silt-sized grains points to the continuous impact of frost weathering processes in the area and considerable transport of fine particles from upslope regions.

\section{Conclusions}

Ground ice and sediment stratigraphy present a useful combination of environmental archives to reconstruct slope evolution at El'gygytgyn Impact Crater in late Pleistocene to Holocene times. The studied accumulative terrace has preserved a late Quaternary record of permafrost formation, variable accumulation rates, climate events including relative thermal maxima and minima, and distinct grain properties resulting from frost weathering. This demonstrates that under certain circumstances, slope sediments and the ground ice contained therein can be used as an indicator of paleo temperature. Additionally, stable paleo surfaces can be reconstructed based on stable hydrochemical signatures in the sediment profile.

Formation of the terrace is seen in connection with the climate transition from the late Pleistocene to Holocene. The apparent increased debris mobilization in this permafrostdominated area suggests a time of climatic transition and geomorphic adjustment to changing climate conditions Vandenberghe, 1995). This may be related to more global factors at the termination of Pleistocene time. Periglacial environmental changes are thought to trigger sediment export into the neighboring El'gygytgyn Crater Lake and results from studying permafrost deposits like ice wedges, texture ice, and sedimentary sequences around the lake and their properties will be integrated into forthcoming paleoclimate reconstructions using the lake sediment record.

\section{Acknowledgments}

Various persons and institutions deserve our thanks. Dr. Olga Glushkova, NEISRI Magadan, helped selecting the study site, the El'gygytgyn scientific party lended hands during the field campaign, Ute Bastian and Antje Eulenburg (both AWI lab), and Dr. Helga Kemnitz (GFZ-SEM lab) helped at various stages of sample processing. Alexander Dereviagin, Olaf Juschus and an anonymous reviewer improved the manuscript through their useful comments, Paul Overduin and Nicole Couture helped with the English and discussions. This work was supported through a grant of the German Ministry for 
Education and Research (BMBF). All contributions are greatly appreciated.

\section{References}

Andreev, A., Tarasov, P., Schwamborn, G., Ilyashuk, B., Ilyashuk, E., Bobrov, A., Klimanov, V., Rachold, V., Hubberten, H.-W., 2004. Holocene paleoenvironmental records from Nikolay Lake, Lena River Delta, Arctic Russia. Paleogeography, Paleoclimatology, Paleoecology 209, 121-197.

Annan, A.P., Davis, J.L., 1976. Impulse radar sounding in permafrost. Radio Science 11, 383-394.

Belyi, V.F., 1998. Impactogenesis and volcanism of the El'gygytgyn depression. Petrology 6 (1), 86-99.

Brigham-Grette, J., 2004. Response to Grosswald and Hughes (2004) — Letter to the Editor. Quaternary Research 62, 227-232.

Burn, C.R., Michel, F.A., Smith, M.W., 1986. Stratigraphic, isotopic and mineralogical evidence for an early Holocene thaw unconformity at Mayo, Yukon Territory. Canadian Journal of Earth Sciences 23, 794-803.

Callahan, J.E., 1987. A nontoxic heavy liquid and inexpensive filters for separation of mineral grains. Journal of Sedimentary Petrology 57, $765-766$.

Craig, H., 1961. Isotopic variations in meteoric waters. Science 133, 1702-1703.

Cremer, H., Wagner, D., 2003. The diatom flora in the ultra-oligotrophic El'gygytgyn Lake, Chukotka. Polar Biology 26, 105-114.

Dansgaard, W., 1964. Stable isotopes in precipitation. Tellus 16 (4), 436-468.

Dereviagin, A.Yu., Chizhov, A.B., Meyer, H., Hubberten, H.-W., Siegert, Ch., 2003. Recent ground ice and its formation on evidence of isotopic analysis. In: Phillips, M., Springman, S.M., Arenson, L.U. (Eds.), Proceedings of 8th International Conference on Permafrost, 21-25 July 2003. Zurich, Switzerland, pp. 5809-5827.

Elzenga, W., Schwan, J., Baumfalk, Y.A., Vandenberghe, J., Krook, L., 1987. Grain surface characteristics of periglacial aeolian and fluvial sands. Geologie en Mijnbouw 65, 273-286.

Fortier, D., Allard, M., 2004. Late Holocene syngenetic ice-wedge polygons development, Bylot Island, Canadian Arctic. Canadian Journal of Earth Sciences 41, 997-1012.

Glushkova, O.Y., 2001. Geomorphological correlation of Late Pleistocene glacial complexes of Western and Eastern Beringia. Quaternary Science Reviews 20, 405-417.

Glushkova, O., 2005. In: Melles, M., Minyuk, P., Brigham-Grette, J., Juschus, O. (Eds.), The Expedition El'gygytgyn Lake 2003 (Siberian Arctic). Reports on Polar and Marine Research, 509, pp. 85-86.

Glushkova, O.Yu., Smirnov, V.N., in press. Pliocene to Holocene geomorphic evolution and paleogeography of the El'gygytgyn Lake region, NE Russia. Journal of Paleolimnology.

Glushkova, O., Lozkhin, A., Minyuk, P., Stetsenko, T., Belaya, B., Cherepanova, M., Brigham-Grette, J., Layer, P., Stone, D., Nolan, M., Anderson, P., Forman, S., Melles, M., Overduin, P., Zielke, A., Nowaczyk, N., 1999. Paleoclimate Data from El'gygytgyn Lake. Russ. Acad. of Sc. Fareast Branch, North-East Interdisciplinary Research Institute (NEISRI), Magadan, Informational Report (in Russian).

Hasholt, B., Hagedorn, B., 2000. Hydrology and geochemistry of river-borne material in a high arctic drainage system, Zackenberg, Northeast Greenland. Arctic, Antarctic, and Alpine Research 32 (1), 84-94.

Heiser, P.M., Roush, J.J., 2001. Pleistocene glaciations in Chukotka, Russia: moraine mapping using satellite synthetic aperture radar (SAR) imagery. Quaternary Science Reviews 20, 393-404.

Hinkel, K.M., Doolittle, J.A., Bockheim, J.G., Nelson, F.E., Paetzold, R., Kimble, J.M., Travis, R., 2001. Detection of subsurface permafrost features with ground-penetrating radar, Barrow, Alaska. Permafrost and Periglacial Processes 12, 179-190.

Hubberten, H.W., Andreev, A., Astakhov, V., Demidov, I., Dowdeswell, J.A., Henriksen, M., Hjort, C., Houmark-Nielsen, M., Jakobsson, M., Kuzmina, S., Larsen, E., Lunkka, J.-P., Lysa, A., Mangerud, J., Möller, P., Saarnisto, M., Schirrmeister, L., Sher, A.V., Siegert, C., Siegert, M.J., Svendsen, J.I., 2004. The periglacial climate and environment in northern Eurasia during the last glaciation. Quaternary Science Reviews 23 (11-13), 1333-1357.
Ispolatov, V.O., Tikhomirov, P.L., Heizler, M., Cherepanova, I.Yu., 2004. New 40Ar/39Ar ages of Cretaceous continental volcanics from Central Chukotka: implications for initiation and duration of volcanism within the northern part of the Okhotsk Chukotka volcanic belt (Northeastern Eurasia). The Journal of Geology 112, 369-377.

Jansen, E., Sjøholm, J., 1991. Reconstruction of glaciation of the past $6 \mathrm{Myr}$ from ice-borne deposits in the Norwegian Sea. Nature 34914 Feb.

Kaplina, T.N., 1981. Permafrost History of North Yakutia During Late Cenozoic Time. Nauka, Moscow, pp. 153-181 (in Russian).

Kaufman, D.S., et al., 2004. Holocene thermal maximum in the western Arctic $\left(0-180^{\circ} \mathrm{W}\right)$. Quaternary Science Reviews 23 (5-6), 529-560.

Konishchev, V.N., Rogov, V.V., 1993. Investigations of cryogenic weathering in Europe and Northern Asia. Permafrost and Periglacial Processes 4, 49-64.

Kotler, E., Burn, C.R., 2000. Cryostratigraphy of the Klondike "muck" deposits, west-central Yukon Territory. Canadian Journal of Earth Sciences 37 (6), 849-861.

Krinsley, D.H., Doornkamp, J.C., 1973. Atlas of quartz sand surface textures. Cambridge Univ. Press. 91 pp.

Kurita, N., Numaguti, A., Sugimoto, A., Ichiyanagi, K., Yoshida, N., 2003. Relationship between the variation of isotopic ratios and the source of summer precipitation in eastern Siberia. Journal of Geophysical Research 108 (10.1029/2001JD001359)

Kurita, N., Yoshida, N., Inoue, G., Chayanova, E.A., 2004. Modern isotope climatology of Russia: a first assessment. Journal of Geophysical Research 109 (10.1029/2003J003404).

Lachenbruch, A.H., 1962. Mechanics of thermal contraction cracks and icewedge polygons in permafrost. Special paper - Geological Society of America 70 (69 pp.).

Layer, P., 2000. Argon-40/argon-39 age of the El'gygytgyn impact event, Chukotka, Russia. Meteoritics and Planetary Science 35, 591-599.

Mackay, J.R., 1974. Ice wedge cracks, Garry Island, NWT. Canadian Journal of Earth Sciences 11, 1366-1383.

J.R., Mackay, 1983. Oxygen isotope variations in permafrost, Tuktoyaktuk Peninsula area, Northwest Territories. In: Current Research, Part B, Geological Survey of Canada, paper 83-1b, 67-74.

Mahaney, W.C., 2002. Atlas of Sand Grain Surface Textures and Applications. Oxford Univ. Press, p. 237.

Melles, M., Minyuk, P., Brigham-Grette, J., Juschus, O. (eds.), 2005. The Expedition El'gygytgyn Lake 2003 (Siberian Arctic). Reports on Polar and Marine Research 509, $139 \mathrm{p}$.

Melles, M., Brigham-Grette, J., Glushkova, O., Minyuk, P., Nowaczyk, N.R., Hubberten, H.-W., in press. Sedimentary geochemistry of a pilot core from El'gygytgyn Lake-A sensitive record of climate variability in the East Siberian Arctic during the past three climate cycles. Journal of Paleolimnology.

Merlivat, L., Jouzel, J., 1979. Global climatic interpretation of the deuteriumoxygen 18 relationship for precipitation. Journal of Geophysical Research 84 (C8), 5029-5033.

Meyer, H., Schönicke, L., Wand, U., Hubberten, H.-W., Friedrichsen, H., 2000. Isotope studies of hydrogen and oxygen in ground ice-Experiences with the equilibration technique. Isotopes in Environmental and Health Studies 36, 133-149.

Meyer, H., Siegert, C., Derevyagin, A., Schirrmeister, L., Hubberten, H.-W., 2002a. Paleoclimate reconstruction on Big Lyakhovsky Island, North Siberia-Hydrogen and oxygen isotopes in ice wedges. Permafrost and Periglacial Processes 13, 91-103.

Meyer, H., Dereviagin, A.Yu., Siegert, C., Hubberten, H.-W., 2002 b. Paleoclimate studies on Bykovsky Peninsula, North Siberia-Hydrogen and oxygen isotopes in ground ice. Polarforschung 70, 37-51.

Michel, F.A., 1982. Isotope Investigations of Permafrost Waters in Northern Canada. Dept. of Earth Sciences, Univ. of Waterloo, Canada, p. 227.

Murton, J.B., French, H., 1994. Cryostructures in permafrost, Tuktoyaktuk coastland, western Arctic, Canada. Canadian Journal of Earth Sciences 31, 737-747.

Nolan, M., Brigham-Grette, J., in press. Basic hydrology, limnology, and meteorology of modern El'gygytgyn Lake, Siberia. Journal of Paleolimnology. Nowaczyk, N.R., Minyuk, P., Melles, M., Brigham-Grette, J., Glushkova, O., 
Nolan, M., Lozkhin, A.V., Stetsenko, T.V., Anderson, P.M., Forman, S.L., 2002. Magnetostratigraphic results from impact crater El'gygytgyn Lake, northeastern Siberia: a $300 \mathrm{kyr}$ long high-resolution terrestrial paleoclimatic record from the Arctic. Geophysical Journal International 150, 109-126.

Ostroumov, V., Hoover, R., Ostroumova, N., Van Vliet-Lanoe, B., Siegert, Ch., Sorokovikov, V., 2001. Redistribution of soluble components during ice segregation in freezing ground. Cold Regions Science and Technology 32, $175-182$

Pisaric, M.F.J., MacDonald, G.M., Velichko, A.A., Cwynar, L.C., 2001. The Lateglacial and Postglacial vegetation history of the northwestern limits of Beringia, based on pollen, stomate and tree stump evidence. Quaternary Science Reviews 20, 235-245.

Popp, S., Diekman, B., Meyer, H., Siegert, Ch., Syromyatnikov, I., Hubberten, H.W., 2006. Palaeoclimate signals as inferred from stable-isotope composition of ground ice in the Verkhoyansk foreland, Central Yakutia. Permafrost and periglacial processes 17, 119-132.

Qui, G., Sheng, W., Huang, C., Zheng, K., 1988. Direction of ion migration during cooling and freezing processes. 5th International Conference on Permafrost, Trondheim, Norway, pp. 442-447. August.

Romanovsky, N.N., 1973. Regularities in formation of frost-fissures and development of frost-fissure polygons. Biuletyn Periglacjalny 23, 237-277.

Romanovsky, N.N., 1976. The scheme of correlation of polygonal wedge structures. Biuletyn Periglacjalny 26, 287-294.

Schirrmeister, L., Siegert, C., Kuznetsova, T., Kuzmina, S., Andreev, A., Kienast, F., Meyer, H., Bobrov, A., 2002. Paleoenvironmental and paleoclimatic records from permafrost deposits in the Arctic region of Northern Siberia. Quaternary International 89, 97-118.

Schirrmeister, L., Grosse, G., Schwamborn, G., Andreev, A.A., Meyer, H., Kunitsky, V.V., Kuznetsova, T.V., Dorozhkina, M.V., Pavlova, E.Y., Bobrov, A.A., Oezen, D., 2003. Late Quaternary history of the accumulation plain north of the Chekanovsky ridge (Lena Delta, Russia): a mulitdisciplinary approach. Polar Geography 27 (4), 277-319.

Schirrmeister, L., 1995. Microfabrics, grain size distributions and grain surface textures in Late Pleistocene basin sediments of Brandenburg (Northern Barnim). Zeitschrift für Geomorphologie. N. F., Supplementband 99, 75-89.

Shilo, N.A., Lozhkin, A.V., Anderson, P.M., Belaya, B.V., Stetsenko, T.V., Glushkova, O.Yu., Brigham-Grette, J., Mellis, M., Minyuk, P.S., Nowaczyk, N., Forman, S., 2001. First continuous pollen record of climate and vegetation changes in the Bering Sea region for the past $300 \mathrm{ka}$. Doklady Akademii Nauk 376, 231-234.

Souchez, R.A., Jouzel, J., 1984. On the isotopic composition in $\delta \mathrm{D}$ and $\delta^{18} \mathrm{O}$ of water and ice during freezing. Journal of Glaciology 30 (106), 369-372.

Stuiver, M., Reimer, P.J., Bard, E., Beck, J.W., Burr, G.S., Hughen, K.A., Kromer, B., McCormac, G., Van der Plicht, J., Spurk, M., 1998. INTCAL98 radiocarbon age calibration, 24,000-0 cal BP. Radiocarbon 40 (3), 1041-1083.

Sugimoto, A., Naito, D., Yanagisawa, N., Ichiyanagi, K., Kurita, N., Kubota, J., Kotake, T., Ohata, T., Maximov, T.C., Fedorov, A.N., 2003. Characteristics of soil moisture in permafrost observed in East Siberian taiga with stable isotopes of water. Hydrological Processes 17, 1073-1092.

Vaikmae, R., 1989. Oxygen isotopes in permafrost and in ground ice-A new tool for paleoclimate investigations. 5th working meeting isotopes in Nature, Leipzig, September, pp. 543-553.

Vaikmae, R., 1991. Oxygen-18 in permafrost ice. Internat. Symposium of the use of isotope techniques in water resources development, pp. 14-26. Vienna, Austria, March.

Vandenberghe, J., 1995. Timescales, climate and river development. Quaternary Science Reviews 14, 631-638.

Van Hoesen, J.G., Orndorff, R.L., 2004. A comparative SEM study on the micromorphology of glacial and nonglacial clasts with varying age and lithology. Canadian Journal of Earth Sciences 41, 1123-1139.

Vasil'chuk, Y.K., 1992. Oxygen isotope composition of ground iceApplication to Paleogeocryological Reconstructions. Moscow, Russia.

Vasil'chuk, Y.K., Vasil'chuk, A.C., 1997. Radiocarbon dating and oxygen isotope variations in Late Pleistocene syngenetic ice-wedges, Northern Siberia. Permafrost and Periglacial Processes 8, 335-345.

Yershov, E.D., 1998. General Geocryology. Studies in Polar Research. Cambridge Univ. Press. English Edition, 580 pp. 